\title{
Renvoi in the Legal System of Afghanistan
}

\section{Lecturer/ Ainullah Karimi}

Member of Academic Cadre of Fiqa and Law Department, Sharia Faculty, Ghazni University, Afghanistan

\section{Email Address: ainullahkarimi.1369@gmail.com}

\section{Lecturer/ Amanullah Zadran}

Member of Academic Cadre of Administrative and Diplomacy Department, Law and Political Science Faculty, Shaikh Zayed University, Afghanistan

\section{Email Address: amanullah.zadran@gmail.com}

\section{Lecturer/ Saeedullah Haneef}

Member of Academic Cadre of Fiqa and Law Department, Sharia Faculty, Ghazni University, Afghanistan

\section{Abstract:}

In the realm of international private law, before a judge can exercise his/her authority to adjudicate a claim, it is necessary to find the governing law under which he/she can make a decision. To achieve his/her goal, the judge is obliged to explain the claim. After that, he/she places it in his respective liaison section, or enforces the conflict resolution rule related to that section, until he/she can reach the ruling law.

In the case of the application of the conflict resolution rule, the judge faces two situations, which are co-ordination and non-coordination of the conflict resolution rules. One form of theirs is called negative conflict or renvoi. And it occurs when the countries involved in the lawsuit, have no authority to intervene and the law of the other country is considered to be justified in handling the lawsuit. 
The goal of this research is to identify the right law and the right court in case of conflict of law in order to better address the issue. That is, if there is a conflict between the laws of countries, it must first be determined whether it is a positive or a negative conflict, so that the problem can be easily resolved. If there is a negative conflict, as a result, the renvoi takes place. For renvoi, the law and the systems of the countries concerned should be studied well in order to resolve the problem easily. As a result of this research, we can understand that in case of a foreign case the judge should try to find foreign righteous law and should make a decision by applying the substantial rules of the righteous law.

Keywords: Renvoi, Classification of Renvoi, Renvoi in the legal system of Afghanistan.

\section{Introduction}

Whenever a legal situation arises due to the relationship between the laws of two or more countries, and each law has different provisions and different consequences for that legal situation, the conflict of laws is required to be discussed.

In other words, the issue of conflict of law arises when it is related to two or more countries in a private relationship rights due to one or more external factors. In such cases, we should know that the law of which of the countries can rule the legal relationship. ${ }^{1}$

For example, suppose that a French husband and wife living in Afghanistan, intending to divorce each other, appeal to an Afghan court for their divorce. The judge, for the first time considering the fact that both are non-Afghan nationals, is faced with the question that which country's law provides for their divorce in a substantive manner? The law of Afghanistan, or the law of France, although Afghanistan is one of the implementing states of the national law in private matters,

it has not accepted any renvoi. Article 43 of the Afghan Civil Law explicitly states: "In cases, where the application of foreign law is anticipated, the subject matter provisions of the said law which are not related to the private law of the country, shall apply. If there is a multiplicity of religions in the law of a state whose provisions are enforceable, the provisions of the religion are determined by the law of that state". ${ }^{2}$

\footnotetext{
${ }^{1}$ Almasi, Nejjad Ali, 1383 Shamsi, Private International Law, Tehran, Mizan Publication. Page: 17

${ }^{2}$ Civil Law of Afghanistan, Official Journal, No. 353, Year 1355, Ministry of Justice, year 1355, Article 34.
} 
Thus, divorce and marriage are considered to be private matters in international private law. Based on it, the Afghan judge must address the issue of divorce of the French husband and wife by referring to the French law, 'The law of the parties' State' and make a decision. Or, for example, an Afghan trader enters into an agreement with a UAE trader in India. According to the agreement, the UAE trader promises to deliver 1,000 tons of the original Indian rice as specified in the contract, which will be submitted to Afghan trader at Chabahar port in Afghanistan. However, the UAE trader does not do it on the due date as he promised.

Now let's suppose that the residence of an Afghan businessman is in Kuwait and the residence of a UAE businessman is in the United Arab Emirates. As Afghan businessmen go to the Afghan court for their rights, the Afghan judge faces a variety of questions, including under which law he/she should address the issue, will the judge address the issue under the law of India where the contract was signed, under the law of Afghanistan which is the place of implementation of the promise, under Kuwaiti law as a place of residence for Afghan national, or under the UAE law which is the second person's native country? Or that the judge should pay no attention to all of the above rules and apply his/her national law on the spot. These all are the issues that come up under the title of conflict of laws.

\section{Discussion}

\subsection{Definition of Renvoi}

Renvoi is a reference to a legal order, which extends from one legal area to another and such reference must be within the realm of international private law. ${ }^{3}$ There are two types of renvoi which are considered debatable in the realm of international private law. (3-4)

\footnotetext{
${ }^{3}$ Dicey, A.V,Morris, J.H and A.L Collins, 1993, P.74 : Mayss, Abla, 1999, P.8.

${ }^{4}$ Naseeri, Mohammad, Shamis, Private International Law, Edition 7, 1380 Shamsi Volume 1 \& 2, Page 181.
} 
For example, if an English couple living in Iran, appeals to an Iranian court for divorce, the renvoi would occur. And if the couple had been living in Denmark and had filed for divorce in an Iranian court, the second case would happen. ${ }^{5}$

\subsection{Types of Renvoi}

There are two types of renvoi, first degree renvoi and second degree renvoi, which are going to be discussed below:

First: the renvoi in which a foreign law applies to the laws of the country in which the case is concerned, is called first degree renvoi.

Second: The renvoi in which a foreign law applies to the law of a third country, is called a second degree renvoi. 6

We briefly examine both types of these situations:

\subsubsection{First Degree of Renvoi}

It is a situation where the law of one country relies on the law of another country to resolve an issue. But the second state again refers the matter to the laws of the first state. For example, a woman and a man who are British nationals, living in France and having a dispute over a personal matter, appeal to the French court to settle the dispute. However, under French law, matters relating to the privacy of foreigners are settled in accordance with the law of their country of origin. On the other hand, under British law, the personal status of an English national is subject to the laws of their residence, so the matter is referred back to France. Although the renvoi may occur repeatedly between the two countries, since the renvoi occurs only in one country, it is called first degree renvoi. ${ }^{7}$

${ }^{5}$ Seljuqi, Mahmoud, Conflict of Laws - Conflict of Powers, 1386 Shamsi , Page 126

${ }^{6}$ Naseeri Page 182

${ }^{7}$ Fadavi, Soleiman, year 1385, conflict of laws in Iran with emphasis on personal Matters, Tehran, Novin Andisheh Publications, Page 108. 
For example, an example of such a situation in international private law is the case of "Forgo" which took place in a French court in the 7th century:

Forgo $^{8}$ was an illegitimate child living in Bavaria and traveling from Bavaria to France at the age of five. He lived there without having any legal documents of staying there, that is, he was not registered with the French government. Forgo eventually died at the age of eight, and under French law his movable property could not be inherited on the basis of his mother's kinship. That is, his movable property was frozen in France, but Bavarian law considered his heirs to be "deserving" of his inheritance, his son and his mother's relatives. In this regard, France finally accepted the rule of thumb and resolved the issue ${ }^{9}$.

\subsubsection{Second Degree Renvoi}

In second degree renvoi, a foreign law which applies to the law of a third country, is called second degree renvoi ${ }^{10}$.

The French judiciary has explicitly accepted the first degree renvoi, although there are many doubts about the second degree renvoi, even though French courts did not accept the Conflict of law until the second half of the twentieth century, but later, his second degree renvoi was also accepted by the French judiciary behavior ${ }^{11}$.

Considering the above example, if the UK does not refer the matter back to France and refers to the laws of any third country, then the issue of marriage of an English citizen in France becomes problematic. Conflicts occur and the French state takes into account the law of the subject state. The law therefore applies only to a person who resides in the United States and is subject to the law of residence in the United Kingdom. The law of the United Kingdom, therefore, refers to the law of the United States of America, so second degree renvoi occurs in the example, because the renvoi is first referred by France to the United Kingdom and then by the United Kingdom to the United States, which is a second degree renvoi.

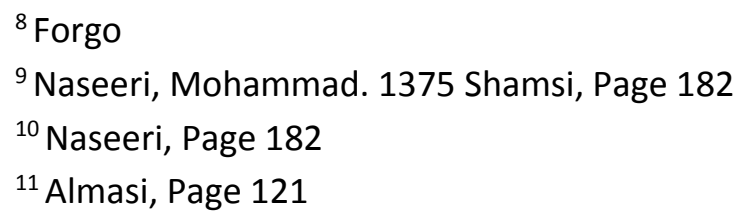




\section{Renvoi in the Legal system of Afghanistan}

As described in the previous discussion, in international private law some countries have accepted the issue of renvoi through judicial process and has been sent to other countries for enactment of laws, but it has not been welcomed by some other countries. Although in some countries the issue of renvoi has been accepted. However, those countries have also recognized first degree renvoi and in some other countries both types of renvoi have been accepted. However, the acceptance or non-acceptance of the subject matter should not be considered internationally as a necessary title in international private law.

Similarly, countries may also be subject to the application of national law or the law of residence, especially in private matters. This is not even the same in systems which consider the politics of making rules about renvoi to be a follower of national law in private matters. For instance, France, Iran, and Italy, are all proponents of the application of national law in matters relating to personal matters, but particularly. There is no consensus among them on the acceptance of national law. In Italy, renvoi has not been accepted, and in Iran, only first-degree renvoi has been taken into consideration ${ }^{12}$.

In France, both renvoi "first degree and second degree" conditions are recognizable ${ }^{13}$.

Although Afghanistan is one of the countries implementing the national law in its personal capacity, which has not accepted any renvoi. Article 43 of the Afghan Civil Law explicitly states: "In cases where the application of foreign law is anticipated, the subject matter provisions of the said law which are subject to international private law shall apply. If there is a multiplicity of religions in the law of a state whose rules are enforceable, then the rules of the religion, which the law of the state has chosen, are applied ${ }^{14 " .}$

According to the mentioned article, in matters relating to the applicability of a foreign law, an Afghan judge must refer to the substantive law of a foreign country, rather than the dispute resolution rule or the international law of that country.

\footnotetext{
${ }^{12}$ Mashayekhi, Mehardad , 1386 Shamsi, Page 57

${ }^{13}$ Mashayekhi, Mehardad, 1386 Shamsi, page 68

${ }^{14}$ Civil Law of Afghanistan, Official Journal, No. 353, Year 1355, Page 34
} 
This view is taken from the views of the opponents of renvoi and does not accept that the law of a foreign country should be considered as a whole, but rather believes in segregation and they are obliged to find out the appropriate law in case of reference to the material laws of a foreign country. Afghan lawmakers have followed rhe same route, citing Egyptian civil law. In Egypt, too, the conflict rules have not been recognized. Article 21 of the Egyptian Civil Law states: Regardless the regulations of the international law, only the rules of internal law are enforceable ${ }^{15}$ " .

Therefore, even in this country, whenever a judge, with the intervention of a foreign factor, refers to his country's conflict resolution rules, he considers foreign law to be dominant, without resorting to foreign law or regulations, proper foreign law directly refers to the material rules and takes steps to resolve disputed cases accordingly ${ }^{16}$.

Therefore, if an English husband and wife demands for a divorce in an Afghan court, the Afghan judge, in accordance with the rules for resolving conflicts of law in his or her country, exercises his or her authority. After retention, he describes the divorce, which is a personal matter, and in accordance with Article 71 of the Civil Law, refers to "English law" which are the laws of the country, the spouses belong to. ${ }^{17}$ Because the law of the British state is known to be righteous in that case. However, since the Afghan legislature has not considered the concept of refinement in accordance with Article 43 of the Civil Law, the Afghan judge has ignored the rules of conflict resolution in British law and so on and assumes that there are no external rules for resolving the dispute and that the judge only sees the substantive rules of English law and implements them. Although Afghanistan is in favor of the implementation of the national law and there are negative contradictions between the rules of conflict resolution between Afghanistan and the United Kingdom, any refusal to accept the issue by the Afghan legislature in Afghanistan will be counted sterile and will not materialize in the country.

${ }^{15} 27^{\text {th }}$ Article of the Egyptian Civil Law

${ }^{16}$ Abdullah, Exaudin, 1986, AD, Page 168

17 17th article of the Civil Law of Afghanistan, Official Journal, No. 353, Year 1355, Ministry of Justice, Kabul: Ministry of Justice. 
Therefore, the renvoi in Afghanistan never changes from a potential state to an actual state. The legislature assumes the head of the court and the Afghan judge to be a person who does not have rules for resolving conflicts with appropriate foreign law and refers to the law of righteousness and makes decision according to the substantive laws.

\section{Conclusion}

A renvoi is a reference to a legal order, which takes place from one legal area to another legal area. Generally, there are two types of identifiable renvoi in the legal systems of countries, one is called first degree and the other is called second degree. Afghanistan is generally considered a national law enforcement country in the legal system and when an Afghan judge is faced with the issue of foreign law enforcement, he or she must refer to the substantive rules of foreign law and make a decision about the case.

In the Afghan legal system, Afghan judges are obliged to find a good law in case of reference to the material or substantial laws of a foreign country. After finding appropriate law, he/she resolves the issues on the basis of material rules. For example, if a British husband resides in Afghanistan, a divorce lawsuit can be filed in a court of the Islamic Republic of Afghanistan. In order to determine the nature of the main element of the claim "divorce" which relates to personal circumstances, it is necessary to find a good law and resolve the issue based on the resolution of the conflicting rules. Therefore, the legal system of Afghanistan, especially the civil law of Afghanistan, does not recognize the concept of renvoi in this regard, therefore, any renvoi in Afghanistan is not considered sterile and achievable .

\section{References}

1. Arfa Nia, Behshid, (1369) Shamsi, Private International Law, Volume 2, Tehran, Agah Publications.

2. Almasi, Nejjad Ali, (1383) Shamsi, Private International Law, Tehran, Mizan Publication.

3. Afzali, Abdul Wahid and Rahimi, Mohammad Ishaq, (1391) Shamsi, Private International Law, First Edition, Tehran: Organization for the Study and Development of Humanities, Samat University, Center for Research and Development of Humanities, Appearance, chapter 72 Page 481 
4. Parvin, Farhad, (1347 AH), another view on the personal affairs of Iranians abroad, Lawstudy.ir.

5. Seljuqi, Mahmoud, (1385 AH), Volume 2, Conflict of Laws - Conflict of Powers, Tehran, Mizan Publishing.

6. Abdullah, Izzal-Din, (1986 AD), Special State Law, Second Part, Cairo, Public Council

7. Fadavi, Soleiman, year (1385), conflict of laws in Iran with emphasis on personal State, Tehran, Novin Andisheh Publications.

8. Civil Law of Afghanistan, Official Journal, No. 353, Year (1355), Ministry of Justice, Kabul: Ministry of Justice.

9. Makrami, Ali Mohammad, year (1375) Shamsi, Private International Law, Volume 2, University Booklet, Faculty of Judicial Sciences and Administrative Services.

10. Madani, Jalaluddin, (1384) Shamis, Private International Law, Fourth Edition, Tehran: Jungle.

11. Mashayekhi, Mehrdad, (1386) Shamsi, in Private International Law, First Edition, Tehran: Arian.

12. Naseeri, Mohammad, (1272) Shamis, Private International Law, Tehran, Agah Publications.

13. Yaghoubi, (1392). Muslim, Brief International Private Law, Volumes 7 and 2, Shamsi, Chatar Danesh Publications.

14. Dicey, A.V, Morris, J.H and A.L Collins, (1993), P.74: Mayss, Abla, 1999, P.8 - 71

15. http: // Mosa - Mosai. Blogfa.com. 2007, P.50 - 51. Huge, Convention of 1955, on Conflict of Law -10

Copyright (C) 2022 Ainullah Karimi, Amanullah Zadran, Saeedullah Haneef, AJRSP. This is an Open-Access Article Distributed under the Terms of the Creative Commons Attribution License (CC BY NC)

Doi: $\underline{\text { doi.org/10.52132/Ajrsp.e.2022.34.1 }}$ 